\title{
Is history of economic thought a "serious" subject?
}

\author{
MARIA CRISTINA MARCUZZO \\ Sapienza, Università di Roma
}

\begin{abstract}
The purpose of this paper is to clarify the nature of research methods in the history of economic thought. In reviewing the "techniques" which are involved in the discipline, four broader categories are identified: a) textual exegesis; b) "rational reconstructions"; c) "contextual analysis"; and d) "historical narrative". After examining these different styles of doing history of economic thought, the paper addresses the question of its appraisal, namely what is good history of economic thought. Moreover, it is argued that there is a distinction to be made between doing economics and doing history of economic thought. The latter requires the greatest possible respect for contexts and texts, both published and unpublished; the former entails constructing a theoretical framework that is in some respects freer, not bound by derivation, from the authors. Finally, the paper draws upon Econlit records to assess what has been done in the subject in the last two decades in order to frame some considerations on how the past may impinge on the future.
\end{abstract}

Keywords: history of economic thought, textual exegesis, rational reconstructions, Econlit records

JEL Classification: A20, B00, B40

In her 1932 booklet dedicated to Piero Sraffa, Joan Robinson addressed the question of whether economics is a serious subject. She did so in the form of an apologia of the economist "to the mathematician, the scientist and the plain man". A serious subject in the academic sense, she claimed, "is neither more nor less than its own technique" (Robinson $1932,3)$. The point she wanted to drive home was that in economics any

AUTHOR'S NotE: This is a revised version of my presidential address to the XXII Conference of the European Society for the History of Economic Thought (ESHET), held in Prague, May 15-17, 2008. I wish to thank, without implicating them, Duncan Foley, Wade Hands, Nerio Naldi, Alessandro Roncaglia, Annalisa Rosselli, and Fernando Vianello, for their comments to an earlier version. 
attempt at more ambitious endeavours (for instance making realistic "assumptions", and giving up abstract and simplified models) is doomed to failure, since the right techniques to tackle the complexity of the real world are often unavailable.

For my address as the first woman president of the European Society for the History of Economic Thought (ESHET) I decided to look to Joan Robinson, for two reasons: firstly as a homage to a great woman economist, and secondly to clarify the nature of research in the history of economic thought (HET). By reviewing which "techniques" are involved in our discipline, my aim is to find out whether for the historian of economic thought, too, there is any need for an apologia to the economist, the historian and the general audience at large.

For this purpose, I identify four broader categories in which HET can be classified: a) textual exegesis; b) "rational reconstructions"; c) "contextual analysis"; and, with a sort of catch-all definition, d) "historical narrative".

Although I refrain from endorsing a ranking of these techniques, my preferences-or, better, my favourite way of doing HET-deriving from my own personal experience and practice, will become apparent. Finally, I will draw upon Econlit records to review what has been done in our subject in the last two decades in order to frame some considerations on how our past may impinge on the future.

\section{TEXTUAL EXEGESIS}

It could be argued that textual exegesis (TE) is the technique par excellence for doing HET. ${ }^{1}$ In return for the toil and trouble of the scholarship-namely the laborious and punctilious skill required in this type of exercise-it accords its practitioners the right to establish the "true" meaning of given texts. This technique defines the scope and method of the professional activity of a historian of economic thought, within the accepted hermeneutic codes.

Stigler (1965) has given us his recipe for good textual exegesis in HET, which encapsulates the demarcation criterion for deciding its scientific character, and which consists of reviewing texts in the light of the interpreter's contemporary economic knowledge. What is required is the ability to reconstruct the general position of "the theoretical core of

\footnotetext{
${ }^{1}$ It may be objected that textual exegesis is a tool that can be applied to any type of HET research. For my purpose, however, it is used to indicate that specific approach centred on "making sense" of a text or a set of propositions.
} 
an author's work [...] in a manner compatible with contemporary economic theory" (Emmett 2003, 525). Since for Stigler "the meaning of the text is determined not by the individual interpreter or even the original author, but by the scientific community of economists" (Emmett 2003, 525), it follows that doing HET is in all relevant respects no different from doing economics, and that any economist will, at least in principle, be endowed with the necessary skills.

Outstanding examples of the Stigler type of TE approach to HET are Hollander's large scale enterprise in interpreting classical political economy and Patinkin's investigation into Keynes's major works. ${ }^{2}$ Far from being uncontroversial, in both cases the interpretations were challenged precisely on the grounds of their readings of the texts being framed by inappropriate theoretical contexts ${ }^{3}$

Hollander's reconstruction of Ricardo's corn ratio theory of profit and Patinkin' s identification of the principle of effective demand in Keynes's early 1930s writings are good examples of trying to make sense of the relevant passages or sentences by employing the logic of the particular neoclassical theory which was standard at the time the interpreter was writing.

\section{RATIONAL RECONSTRUCTIONS}

Rational reconstructions (RR) were the favoured and, indeed, the most popular technique for doing HET in the 1980s and 1990s. The ideas and insights of Smith, Ricardo, Marshall, Keynes, and Schumpeter were reconstructed in the light of either contemporary problems or modern economic analysis. ${ }^{4}$ In just a few praiseworthy cases, investigations were undertaken with philological zest, contextualization, and excursus into unpublished materials, but in most cases the "reconstructions" were made to stand on the shoulders of the contemporary understanding of the issues addressed by past authors.

RR differs from TE in significant respects, the most important of which consists in the reformulation of the arguments of past authors into a modern theoretical framework, rather than "the construction of a theoretical position from the past author's work that can be contrasted with current knowledge" (Emmett 2003, 525).

\footnotetext{
${ }^{2}$ For my purpose, it will suffice to refer here to Hollander 1979; and Patinkin 1982.

${ }^{3}$ For Hollander, see Garegnani 1982; and Peach 1993; for Patinkin, see Kahn 1984.

${ }^{4}$ See Blaug 1990.
} 
But what exactly is the technique identifying the RR mode of doing HET? Formalisation, model building, or other translations into more rigorous economic language are called for. Unlike TE, which is a search into the meaning of a text, $\mathrm{RR}$ is a translation of the ideas of past authors into concepts recognisable to modern eyes by dressing them up with modern tools. Since the two exercises are somewhat different, so are the techniques involved.

A related point is whether RR is used to support existing economic knowledge or to challenge current theory. In the former case, the past is sifted for the predecessors of modern theory and present ideas-I call this a "quest for ascendancy"; while in the latter case the past is searched for what has been lost and can no longer be found in modern theory-I call this a "quest for an alternative". ${ }^{5}$

RR is thus not just a variety of "Whig" history, whereby present-day theory is appointed the judge of the past, but can also be practised as a search into the past for alternatives. Pasinetti's (1974) early work on Ricardo and Keynes can be seen as an outstanding example of the RR approach; alongside Hicks' or Samuelson's incursions into HET, with their reconstruction of Hume-Ricardo-monetary trade theory or Hicks's work on the contributions to monetary theory by classical political economists and Keynes. ${ }^{6}$

However, the pursuit of precursors of contemporary concepts and theories sometimes gives way to what I dub "HET seasoning". This is the technique of identifying ascendancy, or seasoning current economic analysis with references to authors of the past: Keynesian, Schumpeterian, Wicksellian are adjectives intended to add "flavour" to models, such as fixed-price or short-period AS-AD, or endogenous growth, or to interest rate determination in dynamic disequilibrium.

This "HET seasoning" can be performed with more or less concern for the source from which it is derived. For example, when the terms Marshallian or Keynesian are used in analysis of current economic facts or problems, they are interpreted as if the theory explaining them were the same as that formulated by Marshall or Keynes. Thus short period unemployment (i.e., Keynesian equilibrium) or external economies (i.e., dynamic competition) identify special cases of what is assumed to be a more general framework of analysis. Thus, within the RR perspective,

\footnotetext{
${ }^{5}$ See Marcuzzo and Rosselli 2002.

${ }^{6}$ To give only two examples, see Samuelson 1971; and Hicks 1967.
} 
historians of economic thought are seen to give their "serious" contribution to the advancement of knowledge whenever they adapt original concepts to fit contemporary analysis.

The RR mode ceased to be seen as a legitimate and respectable mode of doing HET with the rise of an alternative competing techniquehistorical reconstruction-which endowed HET with a more distinct character and autonomy as a discipline, but was also a factor in alienating the community of historians of economic thought from that of the economists. Historical reconstructions meant mastering a new technique involving, besides the published work, perusal of manuscripts and letters, and in general a familiarity with archival research methods, thus situating HET more firmly in the past rather than the present.

In fact, by making the past its present, HET's scope and concerns shift from textual exegesis and translation into modern economic language, to a more complex, puzzle-solving type of investigation; it requires acquaintance with facts, circumstantial and presumptive evidence, which have legitimacy per se, and not as a subsidiary to economic analysis. There are, however, two varieties of historical reconstruction, which share a straightforward endorsement of the historical method and a common suspicion of rational reconstructions, but differ in some significant respects. The first, I call "contextual analysis" and the other, for want of a better name, "historical narrative".

\section{CONTEXTUAL ANALYSIS}

By context I mean the set of questions and answers which framed theories and concepts, the intellectual interlocutors to whom they were addressed and 'the state of the art' at the time of their conception. The framework consists of facts regarding time, place and circumstances, about which knowledge and information have first to be dug out and then used to make sense of what is being interpreted or, as far as possible, illuminated.

The first conundrum is a matter of source evaluation; in historical investigations we are always confronted with this problem, but as far as HET is concerned there are two aspects to consider: firstly, how related materials, for instance correspondence, stand vis-à-vis purely scientific work (whether published or unpublished); and secondly, in each individual case, the importance of exploring archives rather than relying on published material alone. 
Correspondence is the material upon which biographers build their narrative, providing clues to facts, circumstances and above all motives. Moreover, correspondence helps us place ideas in time and context, and thus leads us to ask questions which would probably not have been asked in those terms.

The second conundrum is theoretical legitimacy: the role of archives in filling the gaps in our knowledge of the personal and intellectual lives of the economists concerned is also unquestionably valid, but what is their value in increasing our grasp of their theories? My answer, drawing on my own work-mostly done jointly with Annalisa Rosselli-is that "papers and correspondence" afford insight into the motivations behind the choices of a particular set of questions, assumptions or tools. These are not always explicitly stated in the published version, where the solutions discarded and definitions abandoned are left out. Archives therefore allow us to travel the road towards a theory rather than, as it were, visit the final destination.

Sraffa's contextual analysis of Ricardo's theory of value and distribution, conducted using unpublished drafts, parliamentary speeches, and correspondence, besides published works, remains the unsurpassed model of scholarship and mastery of this technique (Sraffa 1951-1973). It is the model which has inspired much of my work on the Cambridge approach to economics, attempting to capture the lives and works of Keynes, Kahn, Joan Robinson, and Sraffa in their contexts, drawing on the evidence of the intertwined relationships they formed and the conditions of their times; my aim has been more to grasp their individual and shared concerns, rather than to fit their contributions into a unified core of doctrine.

\section{HISTORICAL NARRATIVE}

More recently, rational reconstructions and philological inquiries have been directed towards "minor" or lesser-known figures, in order to answer to the need to survey the broader picture. It is a sort of "stepping down from the shoulders of giants", searching for less theoryladen investigations, connecting intellectual circles, linking characters and events, mapping "tribes and territories". HET thus appears to be progressively diverted from economic ideas and concepts strictu sensu, bringing in new perspectives and evidence from hitherto unexplored sources, crossing the boundaries of a single discipline to leap into the broader realm of intellectual history. 
Browsing the programmes of the most recent ESHET and HES conferences, or the works awarded recognition as best articles or books by HET societies, this trend can easily be detected. Sessions (or research) on the major classical or neoclassical authors (with the possible exception of Keynes) have shrunk in number and more and more intellectual energy is being devoted to penetrating the less explored territories.

This is a trend which holds particular appeal for young scholars, and it may indeed be a source of misapprehension for those who think that relations with the economic profession should be reinforced, and not loosened. However, some very interesting insights and reconstructions are coming in from these investigations, enlarging and broadening the scope of HET. One should welcome these new openings and encourage the upcoming generation to lead the way.

\section{HET APPRAISAL}

After this very brief overview of the techniques and styles of doing HET, I will now turn to the question of its appraisal. What is good HET? How can or should we appraise it?

This issue was raised by Roy Weintraub in his editorial piece in the HES list (Weintraub 1996). HET, he argued, requires a style of scholarship that is standard among historians (use of primary sources, circumstantial evidence, background knowledge, and so forth), but not among economists. His conclusion was that a "good" economist is not necessarily a "good" historian of economic thought and vice versa.

This line of argument has become increasingly popular since the $1990 \mathrm{~s},{ }^{7}$ being applied to criticise both mainstream and non-mainstream economists as prone to writing mainly "internalist" or even "whig" histories, drawing on their economics rather than mastering the historians' skills.

I personally believe that good HET shows the capacity to be versed in both economic theory and historical methods. It is the combination of these two skills and not simply being knowledgeable in one or the other that makes the difference in the quality of our scientific output. However, I would claim that there is a relevant distinction to be made between doing economics and doing HET.

\footnotetext{
${ }^{7}$ See, for instance, the works by Schabas (1992), Hands (1994), and Henderson (1996).
} 
The task of the "historian" entails close adherence to the reconstruction of theories, personal contributions and the relevant circumstances, requiring the greatest possible respect for contexts and texts, both published and unpublished. The task of the "economist", working on texts and documents but, when expedient, also taking a certain distance from them, entails constructing a theoretical framework that is in some respects freer, and not bound by derivation from the authors. In this respect the theoretician is licensed to compose differences, connecting levels associated with different designs and conceptualisations in diverse authors or in the work of one and the same author.

An example of this distinction between historical and theoretical work which, significantly, has divided and continues to divide the economists working in the Cambridge tradition, has to do with compatibility between the approach of Keynes and the Keynesians, on the one hand, and that of Sraffa and the neo-Ricardians on the other. I feel that in our work as historians we must not be afraid of letting the differences emerge: rather, we must go on bringing to light all those elements of knowledge that offer an understanding of our authors in their historical backgrounds. In our theoretical work we are, in a sense, "freer" to interpret, integrate, and combine concepts and propositions that were quite distinct when formulated. This does not mean taking a cavalier approach to the historian's task but, rather, being clearer about the fact that a different aim is being pursued.

\section{WHOSE HET?}

For an understanding of how HET has actually been practised as opposed to how it should be practised according to some declared norms, it may help to review what has been done in our field in the last 20 years or so. This I did by browsing Econlit on the basis of descriptors B000-B590, which were introduced in 1991; although the classification and the chronology are far from being accurate and acceptable, this affords us a comprehensive overview of the extant HET literature.

Of course it has to be borne in mind that among the top ranked journals in our field only History of Political Economy has full Econlit coverage, while for European Journal for the History of Economic Thought, Journal of the History of Economic Thought, History of Economic Ideas, History of Economic Review the records start from the 
early 1990s. ${ }^{8}$ However, these gaps are partly offset by the presence, up to the late $80 \mathrm{~s}$, of some HET articles in generalist journals such as Journal of Political Economy, Economic Journal, and even American Economic Review.

FIGURE 1

\begin{tabular}{|c|c|c|c|}
\hline \multicolumn{4}{|c|}{ HET ECONLIT DESCRIPTORS POST 1991} \\
\hline B000 & $\begin{array}{l}\text { Schools of Economic Thought and } \\
\text { Methodology: General }\end{array}$ & B250 & $\begin{array}{l}\text { History of Economic Thought since } \\
\text { 1925:Historical; Institutional; } \\
\text { Evolutionary }\end{array}$ \\
\hline B100 & $\begin{array}{l}\text { History of Economic Thought } \\
\text { through 1925: General }\end{array}$ & B290 & $\begin{array}{c}\text { History of Economic Thought since } \\
\text { 1925: Other }\end{array}$ \\
\hline B110 & $\begin{array}{l}\text { History of Economic Thought: } \\
\text { Preclassical (Ancient, Medieval, } \\
\text { Mercantilist, Physiocratic) }\end{array}$ & B300 & $\begin{array}{c}\text { History of Thought: Individuals: } \\
\text { General }\end{array}$ \\
\hline B120 & $\begin{array}{l}\text { History of Economic Thought: } \\
\text { Classical (includes Adam Smith) }\end{array}$ & B310 & History of Thought: Individuals \\
\hline B130 & $\begin{array}{c}\text { History of Economic Thought: } \\
\text { Neoclassical through } 1925 \\
\text { (includes Austrian, Marshallian, } \\
\text { Walrasian) } \\
\end{array}$ & B400 & Economic Methodology: General \\
\hline B140 & $\begin{array}{l}\text { History of Economic Thought } \\
\text { through 1925: Socialist; Marxist }\end{array}$ & B410 & Economic Methodology \\
\hline B150 & $\begin{array}{l}\text { History of Economic Though } \\
\text { through 1925: Historical; } \\
\text { Institutional }\end{array}$ & B490 & Economic Methodology: Other \\
\hline B190 & $\begin{array}{l}\text { History of Economic Thought } \\
\text { through 1925: Other }\end{array}$ & B500 & $\begin{array}{l}\text { Current Heterodox Approaches: } \\
\text { General }\end{array}$ \\
\hline B200 & $\begin{array}{l}\text { History of Economic Thought since } \\
\text { 1925: General }\end{array}$ & B510 & $\begin{array}{l}\text { Current Heterodox Approaches: } \\
\text { Socialist; Marxian; Sraffian }\end{array}$ \\
\hline B210 & $\begin{array}{l}\text { History of Economic Thought: } \\
\text { Microeconomics }\end{array}$ & B520 & $\begin{array}{l}\text { Current Heterodox Approaches: } \\
\text { Institutional; Evolutionary }\end{array}$ \\
\hline B220 & $\begin{array}{l}\text { History of Economic Thought: } \\
\text { Macroeconomics }\end{array}$ & B530 & $\begin{array}{l}\text { Current Heterodox Approaches: } \\
\text { Austrian }\end{array}$ \\
\hline B230 & $\begin{array}{c}\text { History of Economic Thought: } \\
\text { Econometrics; Quantitative Studies }\end{array}$ & B590 & $\begin{array}{l}\text { Current Heterodox Approaches: } \\
\text { Other }\end{array}$ \\
\hline B240 & $\begin{array}{c}\text { History of Economic Thought since } \\
\text { 1925: Socialist; Marxist }\end{array}$ & & \\
\hline
\end{tabular}

Since more than one descriptor can be assigned to each individual record in Econlit, we can sum up all the B descriptor records only by making sure we have eliminated multiple attributions. This I have not

\footnotetext{
${ }^{8}$ HOPE (1969-present); EJHET (Autumn 1993-present); JHET (Spring 1990-present); HEI (1993-present); HER (Winter 1994-present).
} 
attempted to do. However, within each descriptor we can compare the numbers and identify the time profile of each of them.

In the great majority of cases, Econlit records only articles from journals and edited volumes, and books which have been reviewed in JEL, in the latter case with a strong bias for those written in English. Notwithstanding all these limitations, we can get a reasonably reliable picture of HET output over the last 20 years. The following figures offer a bird's-eye view.

FIGURE 2

\begin{tabular}{|c|c|c|c|c|c|c|c|}
\hline CODE & $\begin{array}{l}\text { HET ECONLIT } \\
\text { DESCRIPTORS }\end{array}$ & $\begin{array}{c}\text { N. } \\
\text { PUBBL. }\end{array}$ & $\begin{array}{l}\text { N. } \\
\text { DISS. }\end{array}$ & CODE & $\begin{array}{l}\text { HET ECONLIT } \\
\text { DESCRIPTORS }\end{array}$ & $\begin{array}{l}\text { N. } \\
\text { PUBBL. }\end{array}$ & $\begin{array}{l}\text { N. } \\
\text { DISS. }\end{array}$ \\
\hline B310 & $\begin{array}{l}\text { History of } \\
\text { Thought: } \\
\text { Individuals }\end{array}$ & 10941 & 32 & B200 & $\begin{array}{l}\text { History of Economic } \\
\text { Thought since 1925: } \\
\text { General }\end{array}$ & 639 & 3 \\
\hline B410 & $\begin{array}{l}\text { Economic } \\
\text { Methodology }\end{array}$ & 3868 & 20 & B100 & $\begin{array}{l}\text { History of Economic } \\
\text { Thought through } \\
\text { 1925: General }\end{array}$ & 505 & 3 \\
\hline B220 & $\begin{array}{l}\text { History of } \\
\text { Economic Thought: } \\
\text { macroeconomics }\end{array}$ & 2292 & 8 & B000 & $\begin{array}{l}\text { History of Economic } \\
\text { Thought and } \\
\text { Methodology: General }\end{array}$ & 450 & \\
\hline B120 & $\begin{array}{l}\text { History of } \\
\text { Economic Thought: } \\
\text { Classical }\end{array}$ & 1760 & 9 & B190 & $\begin{array}{l}\text { History of Economic } \\
\text { Thought through } \\
\text { 1925: Other }\end{array}$ & 419 & 2 \\
\hline B250 & $\begin{array}{l}\text { History of } \\
\text { Economic Thought } \\
\text { since 1925: } \\
\text { Socialist; Marxist } \\
\end{array}$ & 1714 & 11 & B530 & $\begin{array}{l}\text { Current Heterodox } \\
\text { Approach: Austrian }\end{array}$ & 409 & 2 \\
\hline B130 & $\begin{array}{l}\text { History of } \\
\text { Economic Thought } \\
\text { Neoclassical } \\
\text { through } 1925\end{array}$ & 1539 & 1 & B230 & $\begin{array}{l}\text { History of Economic } \\
\text { Thought: } \\
\text { Econometrics; } \\
\text { Quantitative and } \\
\text { Mathematical Studies }\end{array}$ & 409 & 3 \\
\hline B520 & $\begin{array}{l}\text { Current Heterodox } \\
\text { Approach: } \\
\text { Institutional; } \\
\text { Evolutionary }\end{array}$ & 1389 & 8 & B290 & $\begin{array}{l}\text { History of Economic } \\
\text { Thought since 1925: } \\
\text { Other }\end{array}$ & 391 & 4 \\
\hline B210 & $\begin{array}{l}\text { History of } \\
\text { Economic Thought: } \\
\text { Microeconomics }\end{array}$ & 908 & 2 & B300 & $\begin{array}{l}\text { History of Thought: } \\
\text { Individuals }\end{array}$ & 254 & 1 \\
\hline B110 & $\begin{array}{l}\text { History of } \\
\text { Economic Thought: } \\
\text { Preclassical }\end{array}$ & 856 & 3 & B500 & $\begin{array}{l}\text { Current Heterodox } \\
\text { Approach: General }\end{array}$ & 149 & 2 \\
\hline B240 & $\begin{array}{l}\text { History of } \\
\text { Economic Thought } \\
\text { since 1925: } \\
\text { Socialist; Marxian } \\
\end{array}$ & 820 & 4 & B320 & Obituaries & 134 & 0 \\
\hline B510 & $\begin{array}{l}\text { Current Heterodox } \\
\text { Approach: } \\
\text { Socialist; Marxian; } \\
\text { Sraffian }\end{array}$ & 794 & 8 & B540 & Feminist Economics & 104 & 0 \\
\hline
\end{tabular}




\begin{tabular}{|c|l|c|c|c|l|c|c|}
\hline $\mathbf{B 1 5 0}$ & $\begin{array}{l}\text { History of } \\
\text { Economic Thought } \\
\text { through 1925: } \\
\text { Historical; } \\
\text { Institutional }\end{array}$ & 743 & 1 & $\mathbf{B 5 9 0}$ & $\begin{array}{l}\text { Current Heterodox } \\
\text { Approaches: Other }\end{array}$ & 45 & 0 \\
\hline $\mathbf{B 4 0 0}$ & $\begin{array}{l}\text { Economic } \\
\text { Methodology: } \\
\text { General }\end{array}$ & 706 & 1 & $\mathbf{B 4 9 0}$ & $\begin{array}{l}\text { Economic } \\
\text { Methodology: Other }\end{array}$ & 39 & 0 \\
\hline B140 & $\begin{array}{l}\text { History of } \\
\text { Economic Thought } \\
\text { through 1925: } \\
\text { Socialist; Marxist }\end{array}$ & 705 & 3 & $\mathbf{B 1 6 0}$ & $\begin{array}{l}\text { History of Economic } \\
\text { Thought: Quantitative } \\
\text { and Mathematical }\end{array}$ & 27 & 0 \\
\hline
\end{tabular}

As to the topics, the highest score is for individual authors, B310-HT: Individuals (10941); followed by B410-Economic Methodology (3868); B220-HET: Macroeconomics (2292); B120-HET: Classical (including Adam Smith) (1760); B250-HET since 1925: Historical, Institutional, Evolutionary, Austrian (1714); and B520-Current Heterodox Approaches: Institutional, Evolutionary (1389).

FIGURE 3

NUMBER OF ECONLIT RECORDS ON AUTHORS

\begin{tabular}{|c|c|c|c|c|c|c|c|}
\hline Smith & 1366 & Samuelson & 170 & Edgeworth & 87 & Cantillon & 42 \\
\hline Keynes & 1207 & Pareto & 148 & Kaldor & 78 & Kahn & 42 \\
\hline Hayek & 599 & Malthus & 147 & Harrod & 74 & Turgot & 42 \\
\hline Marx & 535 & Friedman & 138 & Thornton & 73 & Einaudi & 34 \\
\hline Veblen & 452 & Hicks & 131 & Bentham & 70 & Galiani & 33 \\
\hline Sraffa & 381 & Say & 122 & Quesnay & 69 & Modigliani & 33 \\
\hline Schumpeter & 376 & Wicksell & 121 & Cournot & 63 & Neumann & 29 \\
\hline Marshall & 360 & Kalecki & 119 & Arrow & 62 & Nash & 27 \\
\hline Ricardo & 281 & Knight & 107 & Robertson & 62 & Mandeville & 26 \\
\hline Walras & 230 & Jevons & 106 & Bohm-Bawerk & 58 & Wieser & 23 \\
\hline Mill & 206 & Menger & 104 & Robbins & 54 & Petty & 22 \\
\hline Fisher & 196 & Hume & 98 & Georgescu-Rogen & 43 & & \\
\hline J. Robinson & 193 & Pigou & 93 & Sismondi & 43 & & \\
\hline
\end{tabular}

As to individuals, about 40\% (4540) of the records (10941) are for the top 5 of 50 most studied authors: Smith: 1366; Keynes: 1207; Hayek: 599; Marx: 535; Veblen 452; Sraffa: 381. We may note in passing that the "10 great economists from Marx to Keynes", according to Schumpeter's list (namely, Marx, Walras, Menger, Marshall, Pareto, Bohm-Bawerk, Taussig, Fisher, Mitchell, and Keynes) are very poorly matched in the Econlit ranking of records. 
FIGURE 4

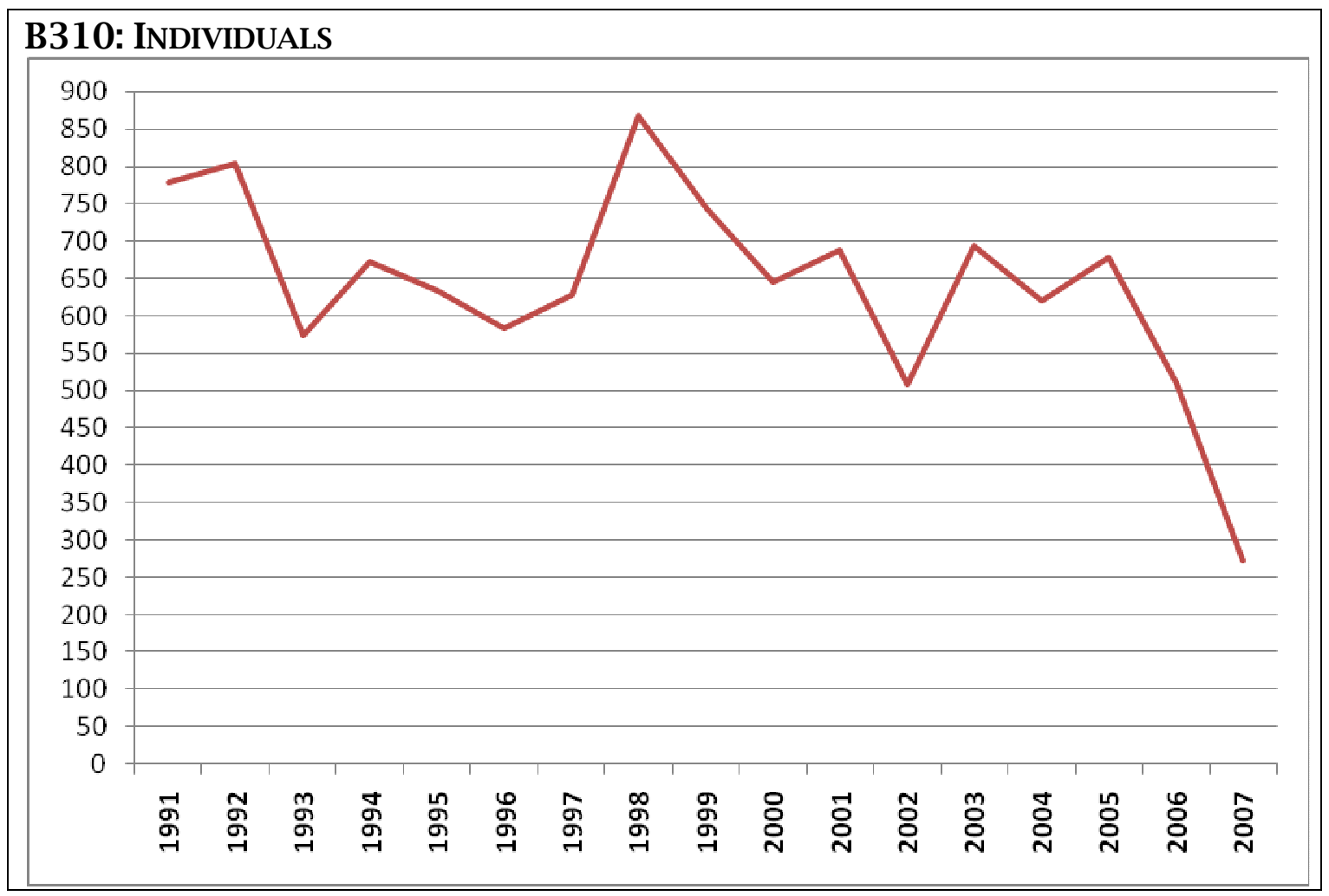

FIGURE 5

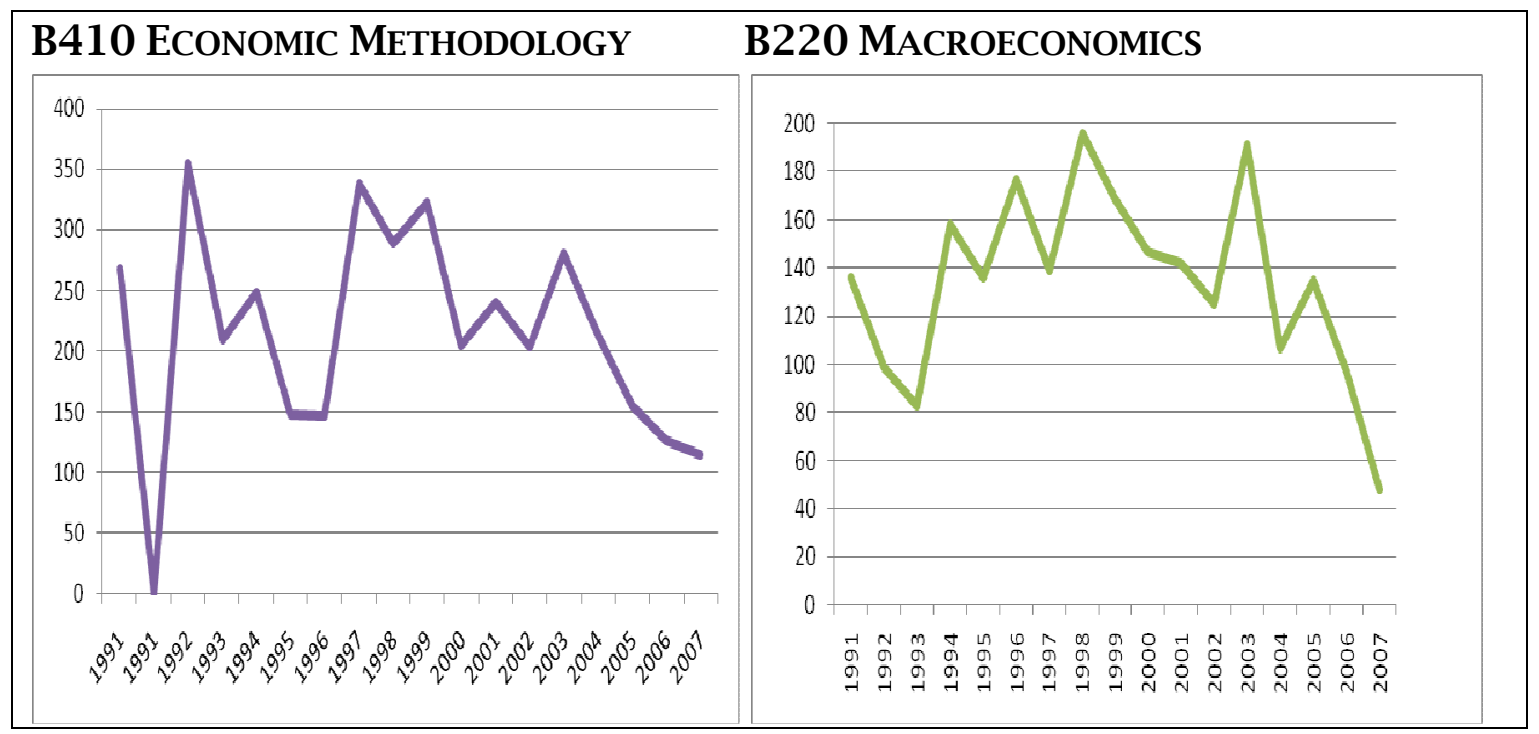


FIGURE 6

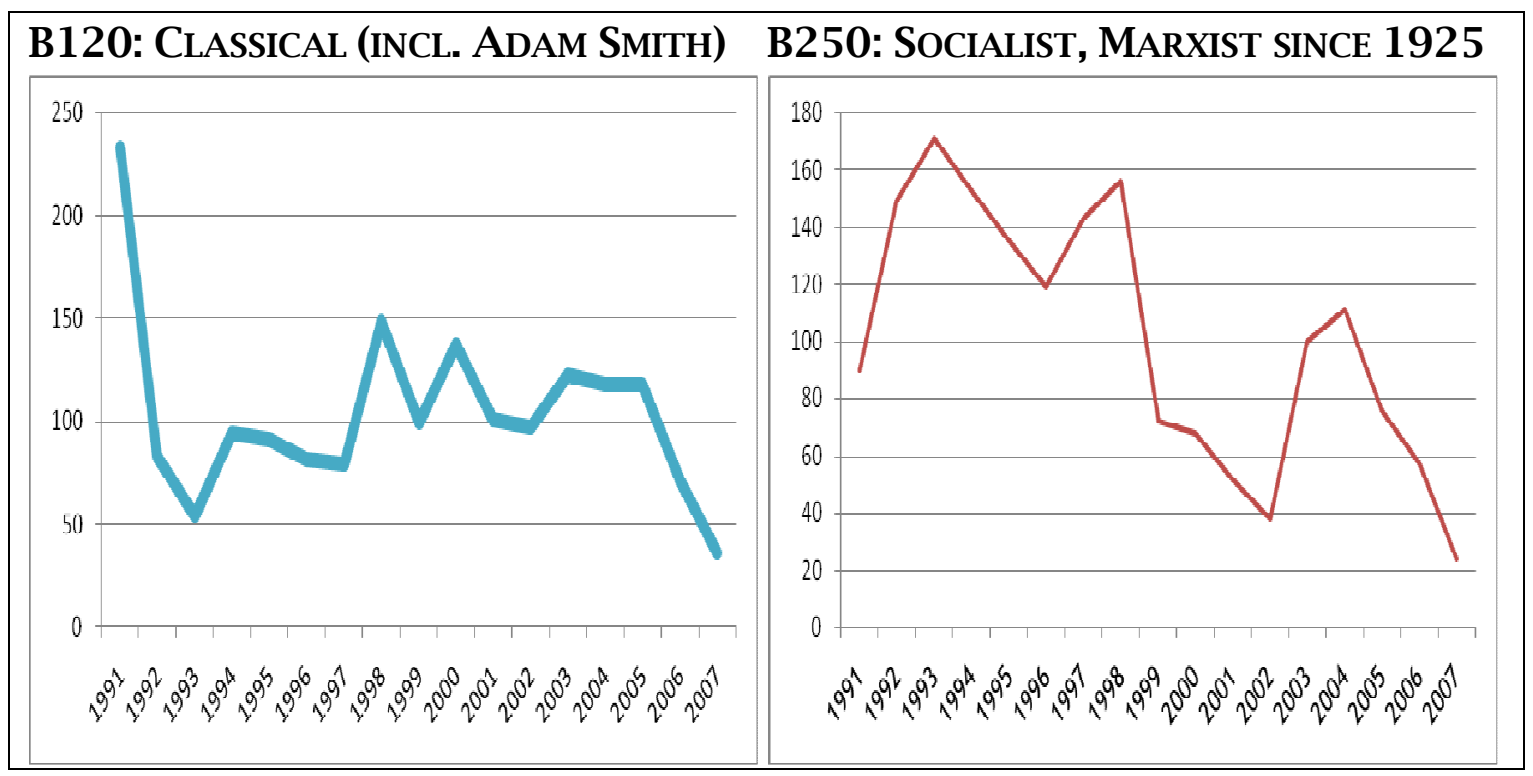

FIGURE 7

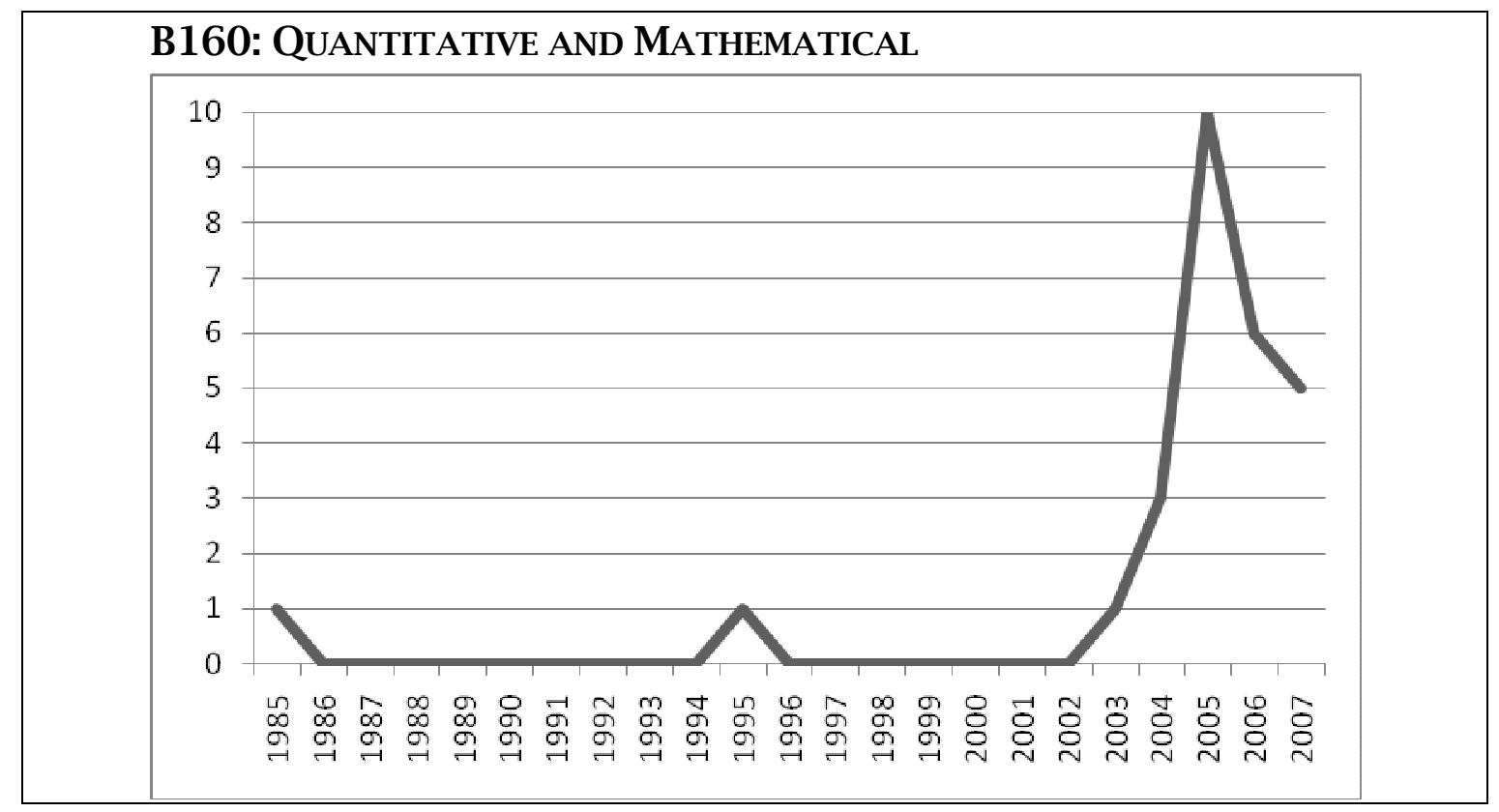

As to the time profile, there is a general tendency for a fall in the numerosity of records, as can be seen by taking the top 5 ranked descriptors, i.e., those with the highest number of records: B310-History of Thought: Individuals (10941); B410-Economic Methodology (3868); B220-HET: Macroeconomics (2292); B120-HET: Classical (1760); with the notable exception of Econometrics and Quantitative Studies, which has the lowest number of records. 
As to the dissertations, although their number is small-totalling only 131 over the relevant period-they give us an interesting picture of the trend in the topics of research in the field (See Fig. 2). To be noticed is that the ranking slightly differs from that of the articles; while the top 2 ranked descriptors in both cases are B310 (History of Thought: Individuals) and B410 (Economic Methodology), the lowest numbers of dissertations are found in topics, such as B130 (History of Thought: Neoclassical through 1925), B210 (HET: Microeconomics) which are ranked among the first ten in the case of articles.

In order to be more significant, the exercise should be extended to the pre-1991 period, converting the old descriptors set to the new one; this would sometimes involve the arbitrary matching of topics and a large computation of records, which I have not attempted to do. Hopefully, however, what I have collected is sufficient to provide some evidence in presenting the outlook of our field in the last 20 years.

\section{RESEARCH AGENDA}

Can the past activity in HET offer us some insights into its trend for the future? Are the gaps likely to be filled and how? I will venture to point to two areas in which I think we may expect some rise in interest and activity.

The first is feminist economics. HET could be an important tool in the work of exposing an impossible neutrality and pervasive genderblindness. ${ }^{9}$ A gender-sensitive reading of past works and theories could open our eyes to the gradual shifts in meaning of the terms, the slow movement of the boundaries of the discipline, the progressive exclusion from it of whole areas of economic activity (housework for example) and of concepts which, though meaningful, lack a quantitative dimension.

The second is the broadening of geographical areas in which we may see interest and country-related research activity blossom in HET. My recent travels to Mexico, India, Japan, and China have proved to me that HET is a vital key to connecting ideas, as well as preserving identity and individual intellectual histories, and this in turn shows that there are indeed ways and means to establish a multicultural rather than monocultural discipline.

HET may help to enhance the ability to speak the same economic language, a necessary requisite of any scientific communication, with

\footnotetext{
${ }^{9}$ For a recent attempt in this direction see Marcuzzo and Rosselli (2008).
} 
awareness of the variety and diversification in approaches to economic ideas and problems. ${ }^{10}$ National societies for the history of economic thought are already there for us to connect and they could play a prominent role in bridging economic cultures and national backgrounds. Personally, I am looking forward to increasingly globalised research activity in HET.

\section{CONCLUSIONS}

I began my paper by asking whether there is any need for an apologia of the historian of economic thought, addressing this question to the economist, the historian, and the general audience at large.

To the economist, I would urge the importance of maintaining in the economics departments keepers of ideas and concepts born in the past, to preserve them from oblivion and the risks of being misused when uprooted from their context. Engaging in conversation and confrontation with contemporary economic discourse is an intellectual duty and while we should be wary of the consequences of alienating ourselves from it, we should make our case as boldly and fearlessly as possible. This is particularly true today, there no longer being a unified, mainstream core in economic analysis.

To the historian, I would plead the importance of ranking our priorities in fact finding and digging into unexplored sources; treasure hunts in economic archives do not have the same pay-off as in much intellectual history and should be done sparingly. Historical investigation should be a benchmark of scholarship for HET, not just another role-model, as mathematics or the natural sciences are for economists.

Finally, to the general audience at large I will make a plea for pluralism in economic analysis, in terms not so much of tools as of ideas. The critical awareness which HET cultivates of how economics is rooted in a given context of interests, ideology, and culture is the road to intellectual freedom and the recipe to advance our knowledge. HET is well placed to cater for the needs of the general public to have this clearly spelt out and understood.

Let me quote from Joan Robinson once again in conclusion: "Economics limps along with one foot in untested hypotheses and the

\footnotetext{
${ }^{10}$ For a recent illustration of the same point, see Foley 2008.
} 
other in untestable slogans. Here our task is to sort out as best we may this mixture of ideology and science" (Robinson 1964, 28).

This is the challenge, the duty, but also the pleasure of doing history of economic thought.

\section{REFERENCES}

Blaug, Mark. 1990. On the historiography of economics. Journal of the History of Economic Thought, 12 (1): 27-37.

Emmett, Ross B. 2003. Exegesis, hermeneutics and interpretation. In The Blackwell companion to the history of economic thought, eds. J. Biddle, J. Davis, and W. Samuels. Oxford: Blackwell, 523-537.

Foley, Duncan K. 2008. The history of economic thought and the political economic education of Duncan Foley. Distinguished Guest Lecture, History of Economics Society Annual Conference, Toronto, June 27-30, 2008.

Garegnani, Pierangelo. 1982. On Hollander's interpretation of Ricardo's early theory of profits. Cambridge Journal of Economics, 6 (1): 65-77.

Hands, D. Wade. 1994. The sociology of scientific knowledge and economics: some thoughts on the possibilities. In New directions in economic methodology, ed. Roger Backhouse. London: Routledge, 75-106.

Henderson, James P. 1996. Whig history is dead: now what? The History of Economics Society Website. HES Archives.

http://eh.net/pipermail/hes/1996-November/004822.html (accessed November 2008).

Hicks, John. R. 1967. Critical essays in monetary theory. Oxford: Clarendon Press.

Hollander, Samuel. 1979. The economics of David Ricardo. Toronto: University of Toronto Press.

Kahn, Richard F. 1984. The making of Keynes's General Theory. Cambridge: Cambridge University Press.

Marcuzzo, M. Cristina, and Annalisa Rosselli. 2002. Economics as history of economics: the Italian case in retrospect. History of Political Economy, 34 (Annual Supplement): 98-109.

Marcuzzo, M. Cristina, and Annalisa Rosselli. 2008. The history of economic thought through gender lenses. In Frontiers in the economics of gender, eds. F. Bettio, and A. Verashchagina. London: Routledge, 3-20.

Pasinetti, Luigi. 1974. Growth and income distribution. Essays in economic theory. Cambridge: Cambridge University Press.

Patinkin, Don. 1982. Anticipations of the General Theory? And other essays on Keynes. Oxford: Blackwell.

Peach, Terry. 1993. Interpreting Ricardo. Cambridge: Cambridge University Press.

Robinson, Joan. 1932. Economics is a serious subject: the apologia of an economist to the mathematician, the scientist and the plain man. Cambridge: Heffer and Son.

Robinson, Joan. 1964. Economic philosophy. Harmondsworth: Penguin, Pelican Books.

Samuelson, Paul A. 1971. An exact Hume-Ricardo-Marshall model of international trade. Journal of International Economics, 1 (1): 1-18.

Schabas, Margaret. 1992. Breaking away: history of economics as history of science. History of Political Economy, 24 (1): 187-203. 
Sraffa, Piero. (ed., with the collaboration of M. Dobb). 1951-1973. D. Ricardo. Works and correspondence, 11 vols. Cambridge: Cambridge University Press.

Stigler, George J. 1965. Textual exegesis as a scientific problem. Economica, 32 (128): 447-450.

Weintraub, Roy. 1996. Legitimate contribution to $\mathrm{H}$ of E. The History of Economics Society Website. HES Archives.

http://eh.net/pipermail/hes/1996-September/005765.html (accessed November 2008).

Maria Cristina Marcuzzo is professor of economics at the University of Rome, "La Sapienza". She is co-author of Ricardo and the gold standard (1991), co-editor of The economics of Joan Robinson (1996), and coauthor of Economists in Cambridge (2005).

Contact e-mail: <cristina.marcuzzo@uniroma1.it> 